\title{
New particle formation events observed at the King Sejong Station, Antarctic Peninsula - Part 2: Link with the oceanic biological activities
}

\author{
Eunho Jang ${ }^{1,2}$, Ki-Tae Park ${ }^{1}$, Young Jun Yoon ${ }^{1}$, Tae-Wook Kim ${ }^{3}$, Sang-Bum Hong ${ }^{1}$, Silvia Becagli ${ }^{4}$, Rita Traversi ${ }^{4}$, \\ Jaeseok Kim $^{5}$, and Yeontae Gim ${ }^{1}$ \\ ${ }^{1}$ Korea Polar Research Institute, 26 Songdomirae-ro, Yeonsu-gu, Incheon 21990, South Korea \\ ${ }^{2}$ University of Science and Technology, 217 Gajeong-ro, Yuseong-gu, Daejeon 34113, South Korea \\ ${ }^{3}$ Division of Environmental Science and Ecological Engineering, Korea University, Seoul, South Korea \\ ${ }^{4}$ Department of Chemistry “Ugo Schiff”, University of Florence, via della Lastruccia, 3, Sesto Fiorentino (FI), 50019, Italy \\ ${ }^{5}$ Korea Research Institute of Standards and Science, 267 Gajeong-ro, Yuseong-gu, Daejeon 34113, South Korea
}

Correspondence: Ki-Tae Park (ktpark@kopri.re.kr)

Received: 9 November 2018 - Discussion started: 14 December 2018

Revised: 26 April 2019 - Accepted: 6 May 2019 - Published: 6 June 2019

\begin{abstract}
Marine biota is an important source of atmospheric aerosol particles in the remote marine atmosphere. However, the relationship between new particle formation and marine biota is poorly quantified. Long-term observations (from 2009 to 2016) of the physical properties of atmospheric aerosol particles measured at the Antarctic Peninsula (King Sejong Station; $62.2^{\circ} \mathrm{S}, 58.8^{\circ} \mathrm{W}$ ) and satellitederived estimates of the biological characteristics were analyzed to identify the link between new particle formation and marine biota. New particle formation events in the Antarctic atmosphere showed distinct seasonal variations, with the highest values occurring when the air mass originated from the ocean domain during the productive austral summer (December, January and February). Interestingly, new particle formation events were more frequent in the air masses that originated from the Bellingshausen Sea than in those that originated from the Weddell Sea. The monthly mean number concentration of nanoparticles $(2.5-10 \mathrm{~nm}$ in diameter) was $>2$-fold higher when the air masses passed over the Bellingshausen Sea than the Weddell Sea, whereas the biomass of phytoplankton in the Weddell Sea was more than $\sim 70 \%$ higher than that of the Bellingshausen Sea during the austral summer period. Dimethyl sulfide (DMS) is of marine origin and its oxidative products are known to be one of the major components in the formation of new particles. Both satellitederived estimates of the biological characteristics (dimethylsulfoniopropionate, DMSP; precursor of DMS) and phyto-
\end{abstract}

plankton taxonomic composition and in situ methanesulfonic acid (84 daily measurements during the summer period in 2013 and 2014) analysis revealed that DMS(P)-rich phytoplankton were more dominant in the Bellingshausen Sea than in the Weddell Sea. Furthermore, the number concentration of nanoparticles was positively correlated with the biomass of phytoplankton during the period when DMS(P)-rich phytoplankton predominate. These results indicate that oceanic DMS emissions could play a key role in the formation of new particles; moreover, the taxonomic composition of phytoplankton could affect the formation of new particles in the Antarctic Ocean.

\section{Introduction}

Aerosols in the atmosphere significantly influence radiative forcing directly (by scattering incoming radiation) and indirectly (by modifying cloud microphysical properties) (IPCC, 2013). Considering that the ocean surface accounts for approximately $70 \%$ of the total surface of the Earth, the marine aerosols are globally one of the most important natural aerosol systems (O'Dowd et al., 2004; Leck and Bigg, 2005; O'Dowd and De Leeuw, 2007). Marine aerosols consist of primary and secondary aerosols. The primary aerosols are produced via the bubble bursting process and include mostly sea salts and organic matter (O'Dowd and De Leeuw, 2007). 
Secondary aerosols (resulting from gas-to-particle conversion) are produced in the marine atmosphere through several different processes (e.g., binary, ternary and ion-induced) (Kulmala and Laaksonen, 1990; Korhonen et al., 1999; Lee et al., 2003; Lovejoy et al., 2004; Kirkby et al., 2016; Jokinen et al., 2018). Biogenic volatile organic compounds emitted into the marine atmosphere through air-sea gas exchange and their oxidative products can be involved in new particle formation events via the nucleation of stable clusters of the order of 0.5-1 nm in size (O'Dowd and De Leeuw, 2007).

In the Antarctic, most submicron aerosol particles are derived from natural sources rather than from long-range transport of anthropogenic sources (Ito, 1989; Kyrö et al., 2013). The Southern Ocean has been considered as the most significant source of secondary organic aerosols in the Antarctic atmosphere, especially during the phytoplankton bloom period (Asmi et al., 2010; Yu and Luo, 2010). Recent studies reported that biological (mostly derived by sea-ice algae) and abiotic (photochemical reaction of halogen compounds) processes occurring near sea-ice regions could significantly influence the formation and growth of aerosol particles (Atkinson et al., 2012; Kyrö et al., 2013; Allan et al., 2015; Dall'Osto et al., 2017, 2018). Molecular level evidence of new particle formation via sequential addition of iodine-containing species, which could be emitted from both open water and sea-ice zones, was reported in the Arctic and Antarctic sites (Sipilä et al., 2016). In addition, the emission of ammonia from seabird colonies in polar regions could act as a key factor contributing to bursts of newly formed particles (Weber et al., 1998; Croft et al., 2016). The Antarctic Peninsula is one of the three areas of the globe facing drastic regional warming, and it undergoes rapid environmental changes (i.e., increased temperature, acidification, shallowing mixed layer depth, sea-ice decline, increased light, increased nutrient supply, reduced salinity and glacial retreat) (Clarke et al., 2007; Deppeler and Davidson, 2017). Such environmental changes in this region could significantly affect the marine ecosystem. Marine phytoplankton influence aerosol properties by releasing various organic compounds back into the atmosphere. The Antarctic Ocean is known to be a significant source of numerous biogenic volatile organic compounds including dimethyl sulfide (DMS), organic nitrogen and halogenated organic compounds (Laturnus et al., 1996; Beyersdorf et al., 2010; Dall'Osto et al., 2017; Giordano et al., 2017). In particular, the Antarctic Ocean is the region with the highest sea-surface DMS concentration (Lana et al., 2011). Observations of both DMS and its oxidative products (i.e., methanesulfonic acid (MSA) and non-seasalt $\mathrm{SO}_{4}^{2-}$ ) in Antarctica show a clear seasonal cycle with a minimum in austral winter and a maximum in austral summer (Prospero et al., 1991; Minikin et al., 1998; Preunkert et al., 2007; Read et al., 2008). DMS is produced by a complex marine biota food-web mechanism (Stefels et al., 2007; Park et al., 2014a). Phytoplankton produce dimethylsulfoniopropionate (DMSP) and then some of the DMSP is con- verted into gaseous DMS through enzymatic cleavage (Simó, 2001). The biogenic emission of DMS from the ocean is the largest natural sulfur source to the atmosphere (Andreae, 1990), and the oxidation of DMS in the marine atmosphere is a key process contributing to the formation of new particles (Park et al., 2017). Once the DMS in the sea surface is emitted into the atmosphere, it is rapidly converted into $\mathrm{SO}_{2}$ and MSA through the photochemical oxidation process. The $\mathrm{SO}_{2}$ and MSA formed from DMS tend to contribute to the formation of new particles via nucleation processes and eventually serve as nuclei for cloud formation (Charlson et al., 1987). Secondary organic aerosols contribute to a large fraction of the submicron aerosol mass in the atmosphere, affecting clouds and climate (Jimenez et al., 2009). However, secondary organic aerosols are a source of considerable uncertainty in understanding current climate change (Shiraiwa et al., 2017). In particular, the formation of new particles in the remote marine atmosphere and their association with marine biota remain poorly quantified.

In this study, we aimed to identify the link between new particle formation and marine biota at a remote Antarctic site, where biological productivity is the highest in the global ocean. To this end, we analyzed the physical and chemical properties of aerosol particles at King Sejong Station $\left(62.2^{\circ} \mathrm{S}, 58.8^{\circ} \mathrm{W}\right)$ on the Antarctic Peninsula from 2009 to 2016. To study the oceanic biological characteristics surrounding the observation site, we analyzed satellitederived estimates including the chlorophyll concentration, total DMSP concentration and taxonomic composition of marine phytoplankton.

\section{Experimental methods}

\subsection{Aerosol measurements}

King Sejong Station $\left(62.2^{\circ} \mathrm{S}, 58.8^{\circ} \mathrm{W}\right)$ is located on the Antarctic Peninsula, where severe climate change is occurring. The aerosol observatory is approximately $400 \mathrm{~m}$ southwest of the main facilities of King Sejong Station and approximately $10 \mathrm{~m}$ above sea level (m a.s.l.). Continuous observations of the physical properties of aerosol particles in the Antarctic atmosphere were conducted between March 2009 and December 2016 at the observatory. The number concentration of aerosol particles $(\mathrm{CN})$ was measured using two condensation particle counters (CPCs) that have different measurement range limits for particle diameter: particles larger than $2.5 \mathrm{~nm}\left(\mathrm{CN}_{2.5}\right.$; TSI model 3776) and particles larger than $10 \mathrm{~nm}\left(\mathrm{CN}_{10}\right.$; TSI model 3772) (Fig. 1a). The difference in the particle number concentration between the two CPCs (i.e., particles between 2.5 and $10 \mathrm{~nm}$ in diameter) was interpreted as an indication of the existence of newly formed nanoparticles $\left(\mathrm{CN}_{2.5-10}\right)$ (Fig. 1b). An Aethalometer (Magee Scientific model AE16) was used to analyze the concentration of black carbon by measuring light-absorbing par- 
ticles at the $880 \mathrm{~nm}$ wavelength. To avoid local influence on the aerosol properties, data with a black carbon concentration of $>100 \mathrm{ng}$ were excluded. Data were also excluded when the wind direction was between 355 and $55^{\circ}$. This is because the northeastern direction is designated the local air pollution sector due to emissions from the power generators and crematory. More detailed information regarding the aerosol particle analysis at King Sejong Station is provided by Kim et al. (2017, 2019).

For analysis of chemical properties of aerosol particles, an air sampler equipped with a $\mathrm{PM}_{10}$ impactor (collecting particles $<10 \mu \mathrm{m}$ in aerodynamic equivalent diameter) was used to collect aerosol particles. The sampler was mounted on the roof of the aerosol observatory and sampled particles every $24 \mathrm{~h}$ during the summer period in 2013 and 2014 (explicitly, from 14 January to 28 February in 2013 and from 2 December 2013 to 18 January 2014). Half of a $47 \mathrm{~mm}$ Teflon filter was used to measure major ions including MSA. The MSA (and the other ions) collected on the filter was extracted into about $10 \mathrm{~mL}$ (18 M $\Omega$ Milli-Q) in ultrasonic bath for $20 \mathrm{~min}$. MSA was determined by an ion chromatography system (Dionex, Thermo Fisher Scientific Inc.) following the procedure described by Becagli et al. (2012). For MSA, reproducibility on real samples was better than $5 \%$. Filter blank concentrations for methanesulfonate were always below the detection limit.

\subsection{Air mass back trajectories}

The air mass back trajectories and meteorological parameters were obtained using the Hybrid Single-Particle Lagrangian Integrated Trajectories model (Draxler and Hess, 1998). In general, the growth rate of submicron particles in the remote marine environment ranges from 0.2 to $5.0 \mathrm{~nm} \mathrm{~h}^{-1}$ (Järvinen et al., 2013; Weller et al., 2015; Kerminen et al., 2018), and the mean growth rate of the aerosol particles measured at the King Sejong Station was approximately $0.7 \pm 0.3 \mathrm{~nm} \mathrm{~h}^{-1}$ during the 8 years (Kim et al., 2019). Therefore, the $2 \mathrm{~d}$ air mass back trajectories and hourly positions were determined and combined with satellite-derived geographical information to identify the travel history of the air mass arriving at the observation site. Daily geographical information on seaice, land and ocean area was obtained from the Sea Ice Index at a $25 \mathrm{~km}$ resolution provided by the National Snow and Ice Data Center (NSIDC). The oceanic region adjacent to the observation site was surrounded by two different ocean basins, namely, the Bellingshausen and Weddell seas. To evaluate the influence of the oceanic biological characteristics on the occurrence of new particle formation, we limited our analysis to the air masses that had exposure predominantly to the ocean area. Specifically, the origin of the hourly air mass arriving at the observation site was divided into two ocean domains (i.e., the Bellingshausen and Weddell seas). Then, all air mass back trajectories were grouped into one of the two ocean domains by only selecting the $2 \mathrm{~d}$ air mass back trajectories that had $>90 \%$ retention in a given ocean domain.

A total of $84 \mathrm{PM}_{10}$ samples for MSA analysis were collected daily during the summer periods in 2013 and 2014. The retention time of the aerosol particles with a diameter $<10 \mu \mathrm{m}$ is known to be approximately $3-5 \mathrm{~d}$ in the atmosphere (Mishra et al., 2004; Budhavant et al., 2015). Therefore, 3, 4 and $5 \mathrm{~d}$ air mass back trajectories were applied to identify the potential origin of MSA during the sampling period.

\subsection{Phytoplankton biomass, DMSP and taxonomic composition analysis}

Satellite-derived ocean color provides a good measure of analyzing the phytoplankton characteristics of the Southern Ocean (Siegel et al., 2013; Haëntjens et al., 2017). The phytoplankton biomass of the two ocean domains was estimated by calculating the chlorophyll concentration from the Moderate Resolution Imaging Spectroradiometer on the Aqua (MODIS-Aqua) satellite at $4 \mathrm{~km}$ resolution during the study period (2009-2016). The trajectory concentration of the air masses originating from the two ocean domains was calculated from the ratio of the number of hourly trajectory points passing over each grid cell $\left(1^{\circ} \times 1^{\circ}\right)$ to the total number of hourly trajectory points (Kim et al., 2011), as shown in Fig. 2a. We limited our analysis of satellitederived chlorophyll concentration to the ocean area for which the trajectory concentration was approximately over $0.1 \%$ $\left(55-65^{\circ} \mathrm{S}, 40-60^{\circ} \mathrm{W}\right.$ for the Weddell Sea and $55-65^{\circ} \mathrm{S}, 60$ $80^{\circ} \mathrm{W}$ for the Bellingshausen Sea). DMSP is produced by marine phytoplankton and is the most important precursor of oceanic DMS production. However, the dependence of the oceanic DMS emission on phytoplankton biomass and DMSP concentration is not straightforward, owing to the strong variabilities across taxonomic groups and the interplay with environmental factors. Nevertheless, temporal and spatial distribution of sea-surface DMSP could be an indicator of contemporary DMS emission. In particular, the DMSPto-chlorophyll ratio could represent the potential DMSproduction capacity of the ocean because the phytoplankton species with higher cellular DMSP content (i.e., higher DMSP-to-chlorophyll ratio) mostly possess an enzyme that can convert cellular DMSP into DMS, whereas phytoplankton species containing lower DMSP content (i.e., lower DMSP-to-chlorophyll ratio) do not have a DMSP cleavage enzyme (Stefels et al., 2007; Park et al., 2014b, 2018). The total DMSP concentration in the sea surface was estimated using the algorithm developed by Galí et al. (2015). The algorithm for the total DMSP concentration was based on the satellite-derived chlorophyll concentration and the light exposure regime (see Supplement for more information). We estimated the taxonomic phytoplankton composition of the two ocean domains using the PHYSAT method. This method is a bio-optic model that was specifically de- 

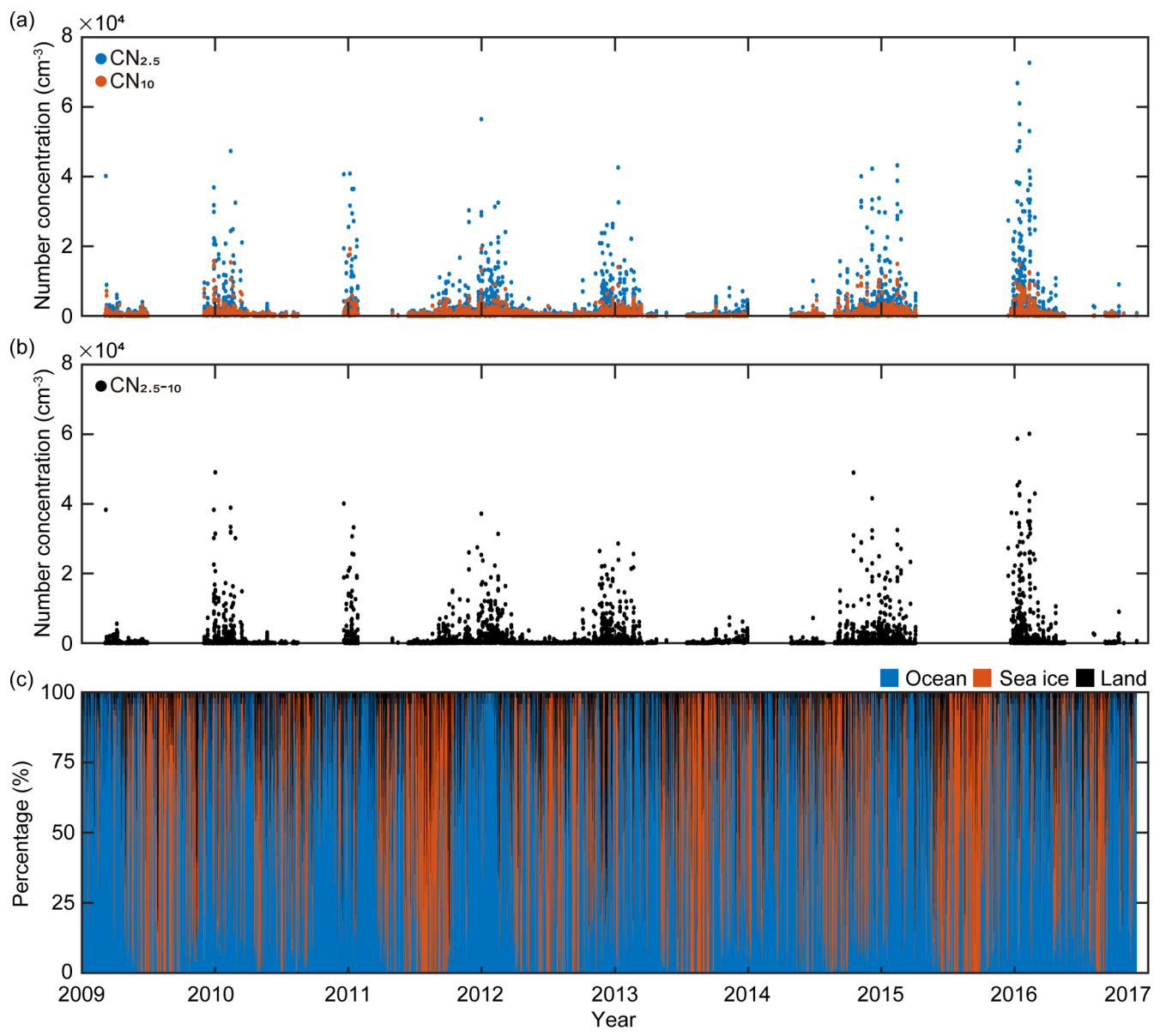

Figure 1. (a) Hourly variations in the number concentration of particles $>2.5 \mathrm{~nm}$ in diameter $\left(\mathrm{CN}_{2.5}\right.$, blue symbols) and the number concentration of particles $>10 \mathrm{~nm}$ in diameter $\left(\mathrm{CN}_{10}\right.$, red symbols), (b) hourly variations in the number concentration of nanoparticles (ranging from 2.5 to $10 \mathrm{~nm}$ in diameter) calculated using the differences between $\mathrm{CN}_{2.5}$ and $\mathrm{CN}_{10}$, and (c) hourly variations in the retention time of $2 \mathrm{~d}$ air mass back trajectories over the three domains including ocean (blue), sea-ice (red), and land (black) domains from March 2009 to November 2016.

veloped to identify the dominant phytoplankton groups from ocean color measurements. Phytoplankton groups are generally characterized by specific pigment, shape and size and have different light scattering and absorption properties (Alvain et al., 2005). The PHYSAT method was first developed in 2005 and was used to classify sea-surface phytoplankton into four groups: diatoms, Prochlorococcus, nanoeucaryotes, and Synechococcus (Alvain et al., 2005). Subsequently, the modified PHYSAT method, which can estimate the contribution of the Phaeocystis group, was reported in 2008 (Alvain et al., 2008). The PHYSAT method was developed and calibrated based on global data obtained from the Sea-Viewing Wide Field-of-View Sensor (SeaWiFS) operated from September 1997 to December 2010. In this study, the monthly dataset of five phytoplankton groups at a resolution of $9 \mathrm{~km}$ was obtained from the PHYSAT database (http: //log.univ-littoral.fr/Physat, last access: 15 Marhc 2019) estimated using climatology over the SeaWiFS period (19972010). Note that "dominant" has been defined as situations in which a given phytoplankton group is a major contributor to the total pigment in a given $9 \mathrm{~km}$ resolution (Alvain et al., 2005, 2008).

\section{Results and discussion}

\subsection{Seasonal variabilities of nanoparticles at King Sejong Station}

The number concentration of aerosol particles increased gradually from early spring, peaked in the austral summer period (December, January and February) and then began to decrease (Fig. 1a). The number concentration of nanoparticles $\left(2.5-10 \mathrm{~nm}\right.$ in diameter, $\left.\mathrm{CN}_{2.5-10}\right)$, which is an indication of newly formed particles, also shows distinct seasonal variation (Fig. 1b). A detailed explanation of physical characteristics of new particle formation events (e.g., frequency, formation rate and growth rate) at King Sejong Station dur- 
(a)
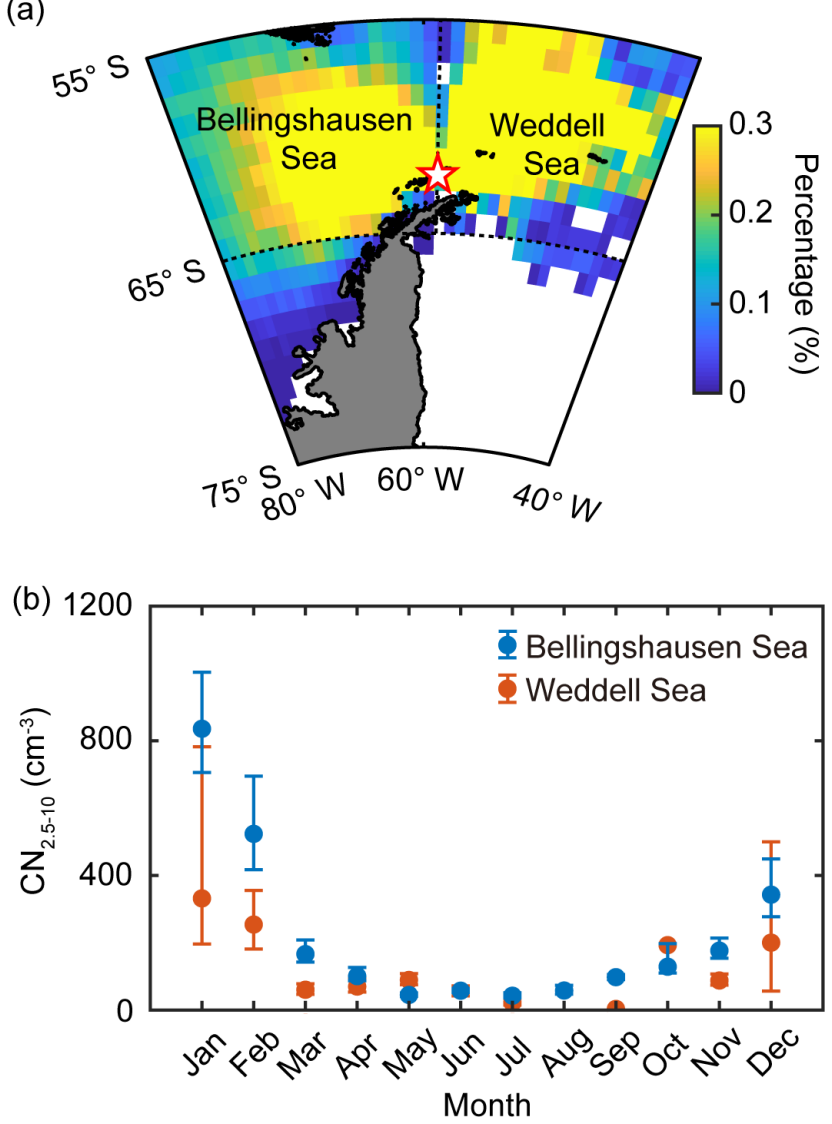

Figure 2. (a) Back trajectories of the air masses arriving at King Sejong Station $\left(62.2^{\circ} \mathrm{S}, 58.8^{\circ} \mathrm{W}\right.$; star symbol), Antarctic Peninsula. The colors indicate the percentage $(\%)$ of the air mass located at that spot during the $2 \mathrm{~d}$ prior to arriving at the observation site. Note that the air mass back trajectories that did not have $>90 \%$ retention in the two selected ocean domains (i.e., Bellingshausen and Weddell seas) were excluded. (b) Seasonal variation of nanoparticles (2.5$10 \mathrm{~nm}$ in diameter, $\mathrm{CN}_{2.5-10}$ ) observed at King Sejong Station between March 2009 and December 2016. Blue and red symbols indicate the number concentration of nanoparticles that originated from the Bellingshausen and Weddell seas, respectively. The error bars indicate the $95 \%$ confidence interval estimated by bootstrap method from the monthly $\mathrm{CN}_{2.5-10}$ data.

ing the same period is explained in Kim et al. (2019). The observation site is surrounded by ocean, sea-ice and land domains, which may influence new particle formation in different ways. The $2 \mathrm{~d}$ air mass back trajectory combined with geographical information showed that approximately $66 \%$ of the hourly trajectory points were assigned to the ocean, followed by sea ice $(29 \%)$ and land $(6 \%)$ during the entire study period (Figs. 1c and S1a in the Supplement). The percentage of hourly trajectory points that passed over the ocean domain was at its maximum during the summer period $(79 \%)$ when the extent of sea ice was at its minimum (Fig. S1b). Kim et al. (2019) reported that a total of 101 days were defined as new particle formation events during the
8 years and 80 days of new particle formation events occurred when the air mass originated from the ocean domain. Furthermore, 16 days of new particle formation events were observed for the air masses originating from the Antarctic Peninsula. The remaining five days of events were considered as those of South American origin (three events) and undefined (two events) (see Kim et al., 2019, for the detailed definition and categorization of new particle formation events). The relationship between new particle formation and environmental parameters is complicated, owing to the interplay among multiple sources and complicated processes. The number concentration of the nanoparticles was at its maximum during the productive summer period, and the frequency of new particle formation was the highest when the air mass originated from the ocean domain. Therefore, we focused on the influence of marine biota on the formation of nanoparticles. The hourly mean concentration of nanoparticles matched with the hourly air mass back trajectory in this study. A total of 22469 hourly mean number concentrations of nanoparticles were measured above the Antarctic atmosphere over the 8 years. Approximately $38.2 \%$ of the hourly mean number concentration of nanoparticles, which satisfies the $>90 \%$ retention of hourly trajectory points over the two ocean domains, was used to estimate the link between new particle formation and the oceanic biological characteristics around the observation site. The remaining $61.8 \%$ of the hourly mean number concentration of nanoparticles, which does not satisfy the $>90 \%$ retention over the two ocean domains, was excluded from further analysis. Interestingly, the monthly mean number concentration of nanoparticles that originated from the Bellingshausen Sea was highest in January $\left(836 \pm 2673 \mathrm{~cm}^{-3}\right)$ and $\sim 2.5$ times greater than that which originated from the Weddell Sea $\left(332 \pm 921 \mathrm{~cm}^{-3}\right.$; Fig. $2 b$ and Table S1). The differences in the number concentration of nanoparticles that originated from the two ocean domains were particularly noticeable during the austral summer period $\left(568 \pm 249 \mathrm{~cm}^{-3}\right.$ for the Bellingshausen Sea and $262 \pm 66 \mathrm{~cm}^{-3}$ for the Weddell Sea). However, the differences were not evident between March and November $\left(97 \pm 51 \mathrm{~cm}^{-3}\right.$ for the Bellingshausen Sea and $73 \pm 57 \mathrm{~cm}^{-3}$ for the Weddell Sea; Fig. 2b).

\subsection{Biological characteristics surrounding the observation site}

In general, the abundance and composition of phytoplankton show distinct spatial and seasonal variation in the Antarctic Ocean (Sullivan et al., 1993). Primary production in the Antarctic Ocean is strongly controlled by various factors such as iron limitation, light availability and mixed layer depth (Arrigo et al., 1999; Sedwick et al., 2007; Park et al., 2013a). The composition of the phytoplankton community is poorly studied in the Antarctic Ocean except for the marginal zone at the Antarctic Peninsula. Nevertheless, both Phaeocystis and diatoms (mainly Phaeocystis antarctica and Fragi- 
lariopsis cylindrus) are well known as dominant phytoplankton groups in the Antarctic Ocean during the phytoplankton bloom period (Kropuenske et al., 2009; Arrigo et al., 2010). Both diatoms and Phaeocystis, considered the most ecologically important phytoplanktonic groups, contribute $>20 \%$ of the global primary productivity and are particularly abundant at high latitudes (Schoemann et al., 2005; Malviya et al., 2016). The monthly mean chlorophyll concentration around the observation site $\left(55-65^{\circ} \mathrm{S}, 40-80^{\circ} \mathrm{W}\right)$ began to increase in October and reached its maximum in November and December during the study period (Fig. S2a). The biological characteristics of the two ocean domains showed notable differences. The monthly mean chlorophyll concentration in the Weddell Sea $\left(0.49 \pm 0.07 \mathrm{mg} \mathrm{m}^{-3}\right)$ was $\sim 70 \%$ higher than that of the Bellingshausen Sea $\left(0.29 \pm 0.05 \mathrm{mg} \mathrm{m}^{-3}\right)$ during the phytoplankton growth period (October-February; Figs. 3a and S2b). The PHYSAT analysis, which was estimated using the SeaWiFS climatology map, revealed that the distribution of the dominant phytoplankton groups showed distinct patterns (Fig. 3c). Diatoms were the most abundant, and the dominance of the diatoms was $\sim 35 \%$ during the austral summer period in the Weddell Sea, followed by nanoeucaryotes (20\%), Phaeocystis (17\%), Prochlorococcus (15\%) and Synechococcus (14\%) (Figs. 3c and S3b). Conversely, the dominance of Phaeocystis increased significantly and accounted for more than $50 \%$ in the Bellingshausen Sea during the austral summer period, while the contribution of the diatoms decreased below $10 \%$ (Figs. 3c and S3a). Although the period considered for the SeaWiFS archive (from September 1997 to December 2010) did not coincide with the period of aerosol particle observation at the King Sejong Station (from March 2009 to December 2016), the PHYSAT analysis performed using the SeaWiFS climatology map was successfully applied to the Southern Ocean and could represent the general seasonal trend of the taxonomic composition of marine phytoplankton in the study area (Alvain and d'Ovidio, 2014; Mustapha et al., 2014). Recently, a regional PHYSAT algorithm for the Mediterranean Sea was developed by applying linear interpolation between SeaWiFS and MODIS wavelengths and reflectance threshold (Navarro et al., 2014). However, challenges remain in high-latitude areas such as the Southern Ocean, especially because of the rather sparse matchup available for the calibration and validation of the PHYSAT algorithm (Alvain et al., 2014).

Enzymatic cleavage of planktonic DMSP into DMS is the major source of DMS, and the production of DMS and DMSP is species-specific. For example, diatoms, picoplankton (i.e., Synechococcus and Prochlorococcus) and most nanoeucaryotes are known to be DMS(P)-poor species. Conversely, Phaeocystis and dinoflagellates have a high cellular DMSP content and many of them possess a DMSP cleavage enzyme that can convert DMSP into gaseous DMS (Keller et al., 1989; Stefels et al., 2007; Park et al., 2014b). The conversion of cellular DMSP into DMS is controlled by not only the concentration of DMSP but also, more importantly, by the DMSP cleavage enzyme. DMS is often produced following the local chlorophyll maxima, leading to a lag period (several weeks to months) (Polimene et al., 2012). This phenomenon is evident when the concentration of DMSP is largely contributed by DMSP-poor species such as diatoms. Most DMSP-poor species do not possess a DMSP cleavage enzyme, and therefore the conversion of DMSP into DMS occurs when the cellular DMSP is released into the ocean as a form of dissolved matter. Subsequently, some dissolved DMSP degrades into gaseous DMS through the bacterial DMSP enzymatic cleavage (Simó, 2001; Stefels et al., 2007). However, a larger proportion of dissolved DMSP is assimilated into bacterial tissues through demethylation processes, which do not produce gaseous DMS (Todd et al., 2007; Reisch et al., 2011). A direct correlation between the local chlorophyll concentration and atmospheric DMS mixing ratio in the absence of lag periods was observed in the Arctic Ocean where Phaeocystis pouchetii (containing both high cellular DMSP and DMSP cleavage enzyme) dominates (Park et al., 2013b). Moreover, the DMS-production capacity in the Arctic Ocean was more significantly controlled by the abundance of DMSP-rich phytoplankton than the total biomass of phytoplankton (Park et al., 2018). These results indicate that the blooming of phytoplankton species containing higher cellular DMSP content results in a much higher DMS-production capacity than the blooming of DMSP-poor phytoplankton species. Therefore, the DMSP-to-chlorophyll ratio is commonly used to explain the differences in taxonomic compositions affecting the oceanic DMS-production capacity (e.g., Belviso et al., 2000; Stefels et al., 2007; Tison et al., 2010; Park et al., 2014b, 2018). In particular, Phaeocystis antarctica was reported to be a dominant species in terms of DMS production in the Antarctic Ocean during the bloom period (Gibson et al., 1990; Schoemann et al., 2005), exhibiting a cellular DMSP concentration in Phaeocystis several times that of diatoms (Hatton and Wilson, 2007; Stefels et al., 2007). The sea-surface DMSP concentration surrounding the observation site was estimated using a newly developed algorithm and was 30\% higher in the Weddell Sea than in the Bellingshausen Sea during the summer period, possibly owing to intense blooming of DMSP-containing diatoms in the Weddell Sea (Figs. 3b and S4a). This could illustrate that, despite having lower cellular DMSP content than Phaeocystis, diatoms dominated the overall DMSP production in the Weddell Sea owing to their much larger biomass. However, the DMSP-to-chlorophyll ratio in the Bellingshausen Sea $\left(110.2 \pm 27.8 \mathrm{mmol} \mathrm{g}^{-1}\right)$ was $\sim 2$-fold higher than that of the Weddell Sea $\left(72.2 \pm 8.3 \mathrm{mmol} \mathrm{g}^{-1}\right)$ between December and February in 2009-2016 (Figs. 3d and S4b), possibly owing to the relatively higher contribution of the DMSP-rich Phaeocystis group in the Bellingshausen Sea. 
(a)

Dec

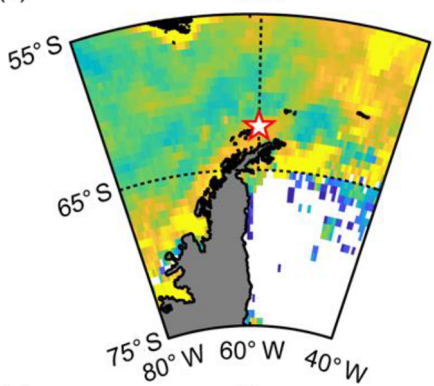

(b)

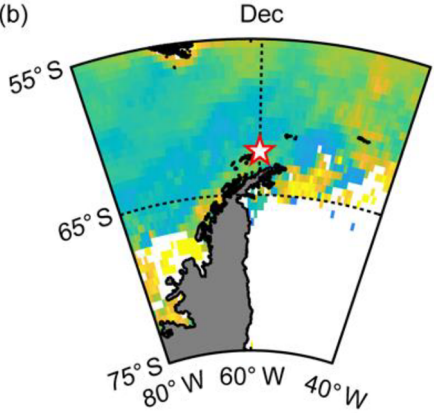

(c)

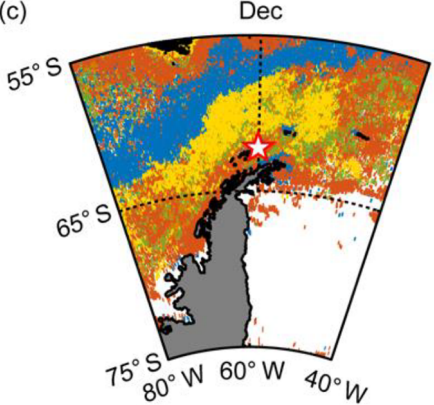

(d)

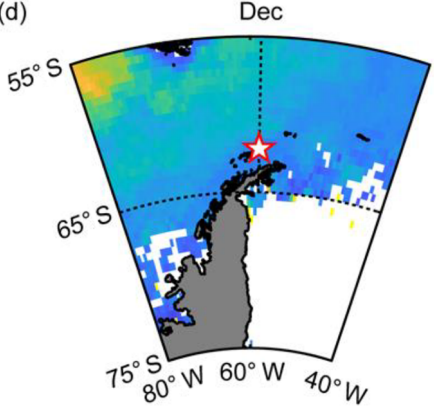

Jan
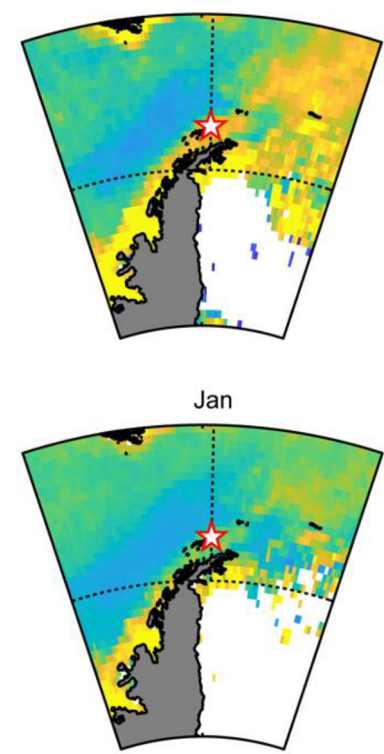

Jan

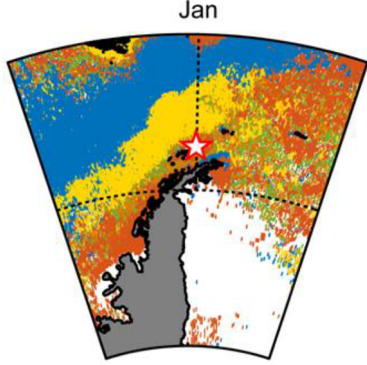

Jan

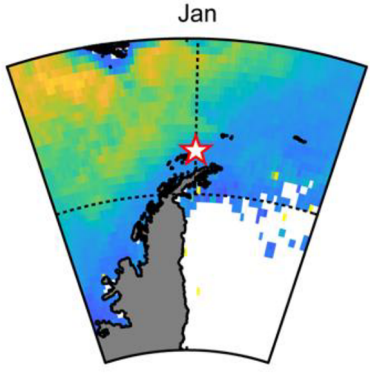

Feb
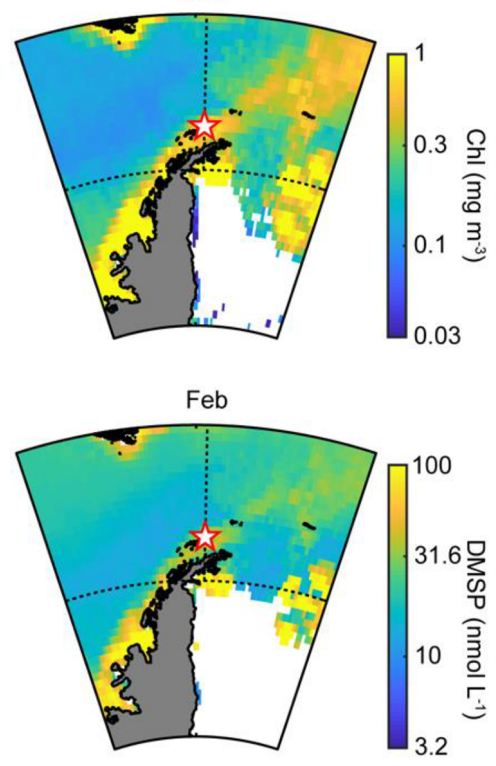

Feb

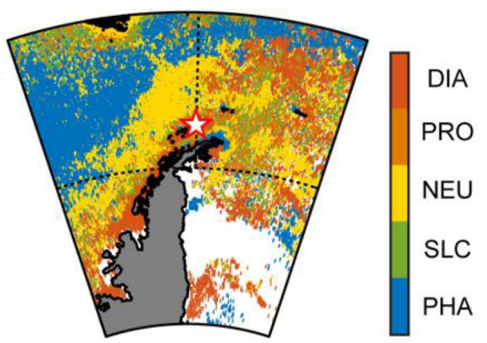

Feb

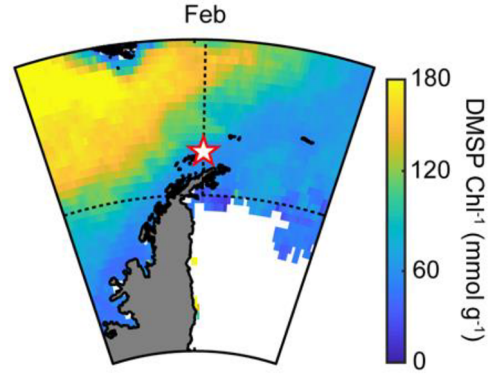

Figure 3. (a) Monthly mean chlorophyll concentration during the months of December, January and February in 2009-2016; (b) monthly mean DMSP concentration during the months of December, January and February in 2009-2016; (c) phytoplankton taxonomic composition including diatoms (DIA), Prochlorococcus (PRO), nanoeucaryotes (NEU), Synechococcus (SLC) and Phaeocystis (PHA) estimated using the PHYSAT method with the climatology map obtained from the SeaWiFS archive; and (d) monthly mean DMSP-to-chlorophyll ratio during the months of December, January and February in 2009-2016.

\subsection{Influence of phytoplankton on aerosol formation}

Biogenic trace gases produced by marine phytoplankton (i.e., DMS, isoprene and halogenated gases) are known to be the key compounds contributing to the formation of new particles in the remote marine environment; however, quantifying the relationship between new particle formation events and marine biology is a major challenge (Brooks and Thornton, 2018). MSA in the marine atmosphere forms exclusively from the photooxidation of DMS and shows strong seasonal variation (Ayers and Gras, 1991; Savoie et al., 1993; Preunkert et al., 2008). A previous study has reported that the highest values for both MSA and the scattering Ångström exponent (SAE; qualitative examination of the aerosol optical 
mean size) were observed at the Marambio Station $\left(64.3^{\circ} \mathrm{S}\right.$, $56.6^{\circ} \mathrm{W}$ ) on the Antarctic Peninsula during austral summer in 2013-2015 (Asmi et al., 2018). The MSA concentration of the fine aerosol particles measured at the King Sejong Station during the summer period in 2013 and 2014 was broadly consistent with the number concentration of nanoparticles. The MSA concentration shows distinct daily variations. The mean MSA concentration was $72.6 \pm 99.1 \mathrm{ng} \mathrm{m}^{-3}$ (ranged from 4.2 to $657.0 \mathrm{ng} \mathrm{m}^{-3}$ ) (Fig. 4a), similar to the values observed at six Antarctic sites during the productive summer period (e.g., Prospero et al., 1991; Minikin et al., 1998; Preunkert et al., 2007; Read et al., 2008; Zhang et al., 2015; Asmi et al., 2018). To identify the potential origin of MSA, air mass back trajectories were determined and the retention time above each domain was averaged for the corresponding $24 \mathrm{~h}$ sampling time. When applying 3, 4 and $5 \mathrm{~d}$ air mass back trajectories, the number of samples that satisfy $>90 \%$ retention in the Bellingshausen and Weddell seas was less than $20 \%$ of the total MSA samples, owing to the longer transport pathway of the fine aerosol particles. Inevitably, the air mass origin of MSA was divided into two sectors, i.e., the Bellingshausen Sea sector $\left(<58.8^{\circ} \mathrm{W}\right)$ and the Weddell Sea sector $\left(>58.8^{\circ} \mathrm{W}\right)$, by selecting the air mass back trajectories with $>50 \%$ retention in a given sector. Although the limited number of samples of MSA (84 samples at daily intervals) collected during the summer periods in 2013 and 2014 may not be sufficient to identify its source origin exactly, the MSA concentration also showed distinct differences depending on the air mass origin. The inflow of the air masses from the Bellingshausen Sea increased the concentration of MSA in the aerosol particles. Notably, the MSA concentration that originated from the Bellingshausen Sea sector $(87.6 \pm 110.0$, $86.6 \pm 110.0$ and $83.9 \pm 109.0 \mathrm{ng} \mathrm{m}^{-3}$ for 3,4 and $5 \mathrm{~d}$ estimates based on air mass back trajectories, respectively) was $\sim 3$ times higher than that which originated from the Weddell Sea sector $\left(27.4 \pm 19.3,30.6 \pm 27.5\right.$ and $33.9 \pm 30.4 \mathrm{ng} \mathrm{m}^{-3}$ for 3, 4 and $5 \mathrm{~d}$ estimates based on air mass back trajectories, respectively) during the austral summer period in 2013-2014 (Fig. 4b). Although the period of satellite observations and in situ chemistry analysis is not exactly the same, both satellitederived biological characteristics and aerosol chemistry data support the interpretation that there was higher abundance of DMS(P)-rich phytoplankton in the Bellingshausen Sea than in the Weddell Sea during the austral summer period (Figs. 3, 4, S2, S3 and S4).

In the 8-year record, the monthly mean chlorophyll concentration was positively correlated with the monthly mean number concentration of nanoparticles for the air masses that originated from the Bellingshausen Sea in January and February $\left(r^{2}=0.69, n=12, P<0.05\right.$; Fig. 5a). During this period, the contribution of the DMS(P)-rich Phaeocystis to the chlorophyll concentration was highest in the Bellingshausen Sea (i.e., DMSP-to-chlorophyll ratio $>100 \mathrm{mmol} \mathrm{g}^{-1}$; dominance of Phaeocystis $>50 \%$; dominance of diatoms $<10 \%$; Figs. 3, S3a and S4). Conversely,
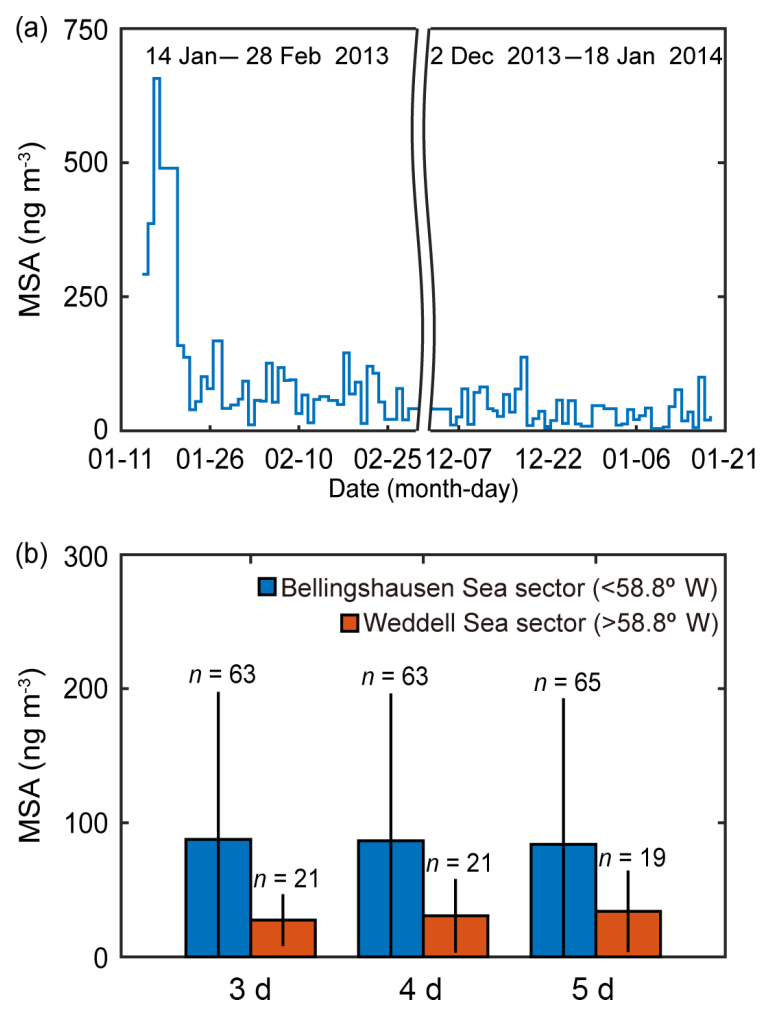

Figure 4. (a) Daily concentration of MSA collected at the sampling site during the summer periods in 2013 and 2014 (explicitly, from 14 January to 28 February in 2013 and from 2 December 2013 to 18 January 2014). (b) The mean MSA concentration that potentially originated from the Bellingshausen Sea sector $\left(<58.8^{\circ} \mathrm{W}\right)$ and the Weddell Sea sector $\left(>58.8^{\circ} \mathrm{W}\right.$ ) estimated by applying 3,4 and $5 \mathrm{~d}$ air mass back trajectories during the austral summer periods in 2013 and 2014. The error bars indicate 1 standard deviation $(1 \sigma)$ from the mean values.

the increase in the chlorophyll concentration was not correlated with the increase in the number concentration of nanoparticles in the Weddell Sea (Fig. 5b). As a consequence, the higher occurrence of nanoparticles from the Bellingshausen Sea inferred from our analysis was likely to be associated with a higher abundance of DMS(P)-rich phytoplankton, whereas the lower occurrence of nanoparticles from the Weddell Sea appeared to be associated with a higher abundance of DMS(P)-poor phytoplankton.

\section{Conclusions}

The physical properties of aerosol particles measured above the remote Antarctic Peninsula over 8 years were analyzed in conjunction with the satellite-derived biological characteristics around the observation site. These results show that the formation of nanoparticles was strongly associated not only with the biomass of phytoplankton but, more importantly, also its taxonomic composition in the Antarctic Ocean. Pre- 

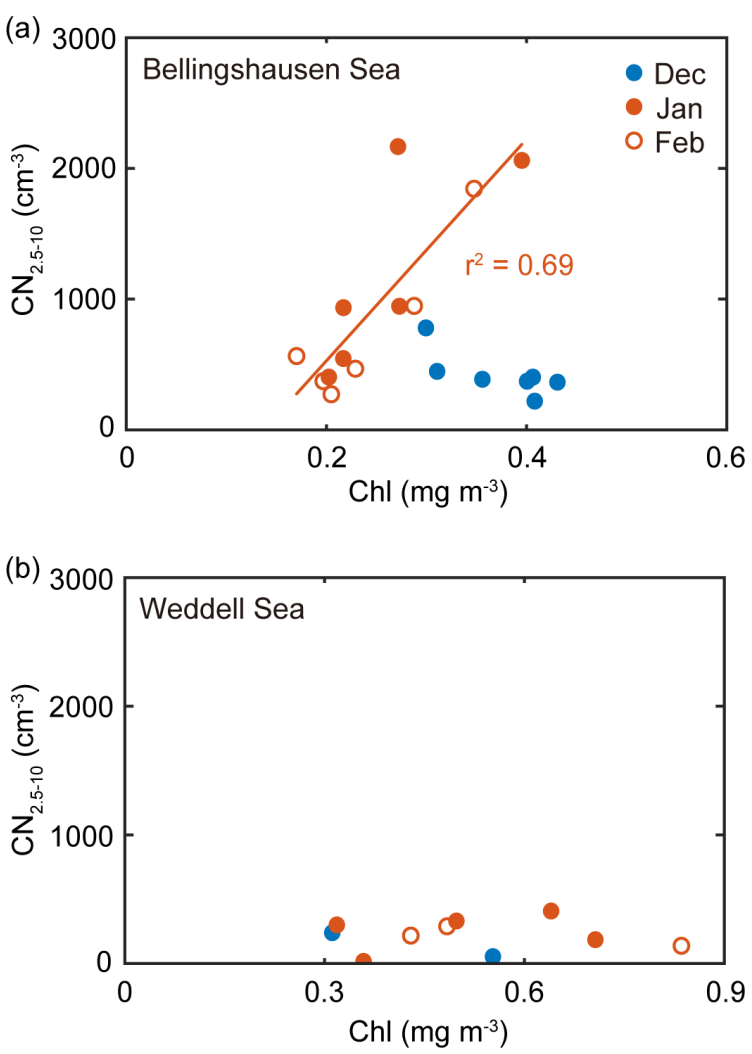

Figure 5. (a) Relationship between the monthly mean chlorophyll concentration for the Bellingshausen Sea $\left(55-65^{\circ} \mathrm{S}, 60-80^{\circ} \mathrm{W}\right)$ and the monthly mean number concentration of nanoparticles that originated from the Bellingshausen Sea in 2009-2016. (b) Relationship between the monthly mean chlorophyll concentration for the Weddell Sea $\left(55-65^{\circ} \mathrm{S}, 40-60^{\circ} \mathrm{W}\right)$ and the monthly mean number concentration of nanoparticles that originated from the Weddell Sea in 2009-2016. The filled blue, filled red and open red symbols indicate the data obtained in December, January and February, respectively. The solid lines represent the best fit.

vious studies have reported that diatoms have a competitive advantage under conditions in which the mixed layers are shallow and the light levels are relatively high. Conversely, Phaeocystis is well adapted to conditions in which mixed layers are deep and light levels are variable (e.g., Weber and El-Sayed, 1987; Arrigo et al., 1999, 2010; Goffart et al., 2000; Alvain et al., 2008). These results are consistent with the distribution of phytoplankton groups in the Bellingshausen and Weddell seas. Given that the mixed layer depth in the Bellingshausen Sea (45.6 $\pm 4.1 \mathrm{~m})$ was relatively deeper than that of the Weddell Sea $(36.2 \pm 3.8 \mathrm{~m}$; Fig. S6) during the austral summer period, the growth of DMS(P)rich Phaeocystis may therefore be more favorable in the Bellingshausen Sea. Sea-surface warming and freshening is commonly associated with a shallowing of the mixed layer depth (Capotondi et al., 2012). The warming trend has shown the spatial complexity across the Antarctic Ocean in recent decades (Turner et al., 2005). Therefore, all regions of the
Antarctic Ocean will experience different changes in phytoplankton productivity and taxonomic composition in response to the climate change (Deppeler and Davidson, 2017).

In this study, we have focused on the relationship between the formation of nanoparticles and marine biota. The formation of secondary aerosols contributes significantly to the atmospheric aerosol number and accounts for 30\%-80\% of the global cloud condensation nuclei (Merikanto et al., 2009; Westervelt et al., 2014; Sanchez et al., 2018; Sullivan et al., 2018). Our results indicate that changes in the taxonomic composition of marine phytoplankton (i.e., DMS(P)rich species vs. DMS(P)-poor species) could have a significant impact on the aerosol properties in the remote marine environment. Precursors other than biogenic DMS could play a key role in the formation of new particles in the Antarctic atmosphere. In fact, 16 days of new particle formation events out of 101 events were observed when the air mass originated from the Antarctic Peninsula during the study period. Penguin colonies are dispersed throughout the Antarctic Peninsula (Croxall et al., 2002), and the emission of ammonia from these colonies could trigger the formation of nanoparticles (Weber et al., 1998; Croft et al., 2016). Moreover, iodine molecules produced by biotic and abiotic processes near sea-ice regions are known to influence the formation of aerosol particles (Allan et al., 2015; Sipilä et al., 2016). Future studies are required to minimize the knowledge gaps related to multiple precursors and their source origins. Specifically, continuous measurements of the physiochemical properties of aerosol particles and molecular-scale measurements of chemical species (e.g., sulfur-, nitrogen-, and halogen-containing compounds) involved in nucleation processes are required to provide direct evidence for the contribution of these compounds to the formation and growth of aerosol particles and to understand their climate feedback roles in the remote marine environment.

Data availability. The data used in this publication will be readily provided upon request to the corresponding author (ktpark@kopri.re.kr).

Supplement. The supplement related to this article is available online at: https://doi.org/10.5194/acp-19-7595-2019-supplement.

Author contributions. KTP, JEH, JSK, TWK and YYJ designed the study. YYJ and YTG analyzed the physical properties of the aerosol particles. HSB, SB and RT operated the air sampler and analyzed the MSA. KTP and JEH wrote the manuscript. KTP and JEH contributed equally to this work.

Competing interests. The authors declare that they have no conflict of interest. 
Acknowledgements. We thank the overwintering staff for assisting us in maintaining the aerosol equipment at the King Sejong Station.

Financial support. This research has been supported by the Korea Polar Research Institute (grant no. PE19010 and PE19140).

Review statement. This paper was edited by Veli-Matti Kerminen and reviewed by three anonymous referees.

\section{References}

Allan, J. D., Williams, P. I., Najera, J., Whitehead, J. D., Flynn, M. J., Taylor, J. W., Liu, D., Darbyshire, E., Carpenter, L. J., Chance, R., Andrews, S. J., Hackenberg, S. C., and McFiggans, G.: Iodine observed in new particle formation events in the Arctic atmosphere during ACCACIA, Atmos. Chem. Phys., 15, 55995609, https://doi.org/10.5194/acp-15-5599-2015, 2015.

Alvain, S., Moulin, C., Dandonneau, Y., and Breon, F. M.: Remote sensing of phytoplankton groups in case 1 waters from global SeaWiFS imagery, Deep-Sea Res. Pt. I, 52, 1989-2004, https://doi.org/10.1016/j.dsr.2005.06.015, 2005.

Alvain, S., Moulin, C., Dandonneau, Y., and Loisel, H.: Seasonal distribution and succession of dominant phytoplankton groups in the global ocean: A satellite view, Global Biogeochem. Cy., 22, GB3001, https://doi.org/10.1029/2007gb003154, 2008.

Alvain, S. and d'Ovidio, F.: Phytoplankton diversity in the Southern Ocean: a satellite view, in: Biogeographic Atlas of the Southern Ocean, edited by: Broyer, C. D., Koubbi, P., Griffiths, H. J., Raymond, B., and d'Udekem d'Acoz, C., Scientific Committee on Antarctic Research, Cambridge, UK, 260-265, 2014.

Andreae, M. O.: Ocean-Atmosphere Interactions in the Global Biogeochemical Sulfur Cycle, Mar. Chem., 30, 1-29, https://doi.org/10.1016/0304-4203(90)90059-L, 1990.

Arrigo, K. R., Robinson, D. H., Worthen, D. L., Dunbar, R. B., DiTullio, G. R., VanWoert, M., and Lizotte, M. P.: Phytoplankton community structure and the drawdown of nutrients and $\mathrm{CO}_{2}$ in the southern ocean, Science, 283, 365-367, https://doi.org/10.1126/science.283.5400.365, 1999.

Arrigo, K. R., Mills, M. M., Kropuenske, L. R., van Dijken, G. L., Alderkamp, A.-C., and Robinson, D. H.: Photophysiology in two major southern ocean phytoplankton taxa: photosynthesis and growth of Phaeocystis antarctica and Fragilariopsis cylindrus under different irradiance levels, Integr. Comp. Biol., 50, 950-966, https://doi.org/10.1093/icb/icq021, 2010.

Asmi, E., Frey, A., Virkkula, A., Ehn, M., Manninen, H., Timonen, H., Tolonen-Kivimäki, O., Aurela, M., Hillamo, R., and Kulmala, M.: Hygroscopicity and chemical composition of Antarctic sub-micrometre aerosol particles and observations of new particle formation, Atmos. Chem. Phys., 10, 4253-4271, https://doi.org/10.5194/acp-10-4253-2010, 2010.

Asmi, E., Neitola, K., Teinilä, K., Rodriguez, E., Virkkula, A., Backman, J., Bloss, M., Jokela, J., Lihavainen, H., De Leeuw, G., Paatero, J., Aaltonen, V., Mei, M., Gambarte, G., Copes, G., Albertini, M., Fogwill, G. P., Ferrara, J., Barlasina, M. E., and Sánchez, R.: Primary sources control the variability of aerosol optical properties in the Antarctic Peninsula, Tellus B,
70, 1414571, https://doi.org/10.1080/16000889.2017.1414571, 2018.

Atkinson, H. M., Huang, R.-J., Chance, R., Roscoe, H. K., Hughes, C., Davison, B., Schönhardt, A., Mahajan, A. S., Saiz-Lopez, A., Hoffmann, T., and Liss, P. S.: Iodine emissions from the sea ice of the Weddell Sea, Atmos. Chem. Phys., 12, 11229-11244, https://doi.org/10.5194/acp-12-11229-2012, 2012.

Ayers, G. P. and Gras, J. L.: Seasonal relationship between cloud condensation nuclei and aerosol methanesulphonate in marine air, Nature, 353, 834-835, https://doi.org/10.1038/353834a0, 1991.

Becagli, S., Scarchilli, C., Traversi, R., Dayan, U., Severi, M., Frosini, D., Vitale, V., Mazzola, M., Lupi, A., Nava, S., and Udisti, R.: Study of present-day sources and transport processes affecting oxidised sulphur compounds in atmospheric aerosols at Dome C (Antarctica) from yearround sampling campaigns, Atmos. Environ., 52, 98-108, https://doi.org/10.1016/j.atmosenv.2011.07.053, 2012.

Belviso, S., Christaki, U., Vidussi, F., Marty, J.-C., Vila, M., and Delgado, M.: Diel variations of the DMSP-to-chlorophyll a ratio in Northwestern Mediterranean surface waters, J. Marine Syst., 25, 119-128, https://doi.org/10.1016/S0924-7963(00)00011-7, 2000.

Beyersdorf, A. J., Blake, D. R., Swanson, A., Meinardi, S., Rowland, F. S., and Davis, D.: Abundances and variability of tropospheric volatile organic compounds at the South Pole and other Antarctic locations, Atmos. Environ., 44, 4565-4574, https://doi.org/10.1016/j.atmosenv.2010.08.025, 2010.

Brooks, S. D. and Thornton, D. C. O.: Marine Aerosols and Clouds, Annu. Rev. Mar. Sci., 10, 289-313, https://doi.org/10.1146/annurev-marine-121916-063148, 2018.

Budhavant, K., Safai, P. D., and Rao, P. S. P.: Sources and elemental composition of summer aerosols in the Larsemann Hills (Antarctica), Environ. Sci. Pollut. R., 22, 2041-2050, https://doi.org/10.1007/s11356-014-3452-0, 2015.

Capotondi, A., Alexander, M. A., Bond, N. A., Curchitser, E. N., and Scott, J. D.: Enhanced upper ocean stratification with climate change in the CMIP3 models, J. Geophys. Res., 117, C04031, https://doi.org/10.1029/2011JC007409, 2012.

Charlson, R. J., Lovelock, J. E., Andreae, M. O., and Warren, S. G.: Oceanic Phytoplankton, Atmospheric Sulfur, Cloud Albedo and Climate, Nature, 326, 655-661, https://doi.org/10.1038/326655a0, 1987.

Clarke, A., Murphy, E. J., Meredith, M. P., King, J. C., Peck, L. S., Barnes, D. K., and Smith, R. C.: Climate change and the marine ecosystem of the western Antarctic Peninsula, Philos. T. Roy. Soc. B, 362, 149-166, https://doi.org/10.1098/rstb.2006.1958, 2007.

Croft, B., Wentworth, G. R., Martin, R. V., Leaitch, W. R., Murphy, J. G., Murphy, B. N., Kodros, J. K., Abbatt, J. P., and Pierce, J. R.: Contribution of Arctic seabird-colony ammonia to atmospheric particles and cloud-albedo radiative effect, Nat. Commun., 7, 13444, https://doi.org/10.1038/ncomms13444, 2016.

Croxall, J. P., Trathan, P. N., and Murphy, E. J.: Environmental change and Antarctic seabird populations, Science, 297, 15101514, https://doi.org/10.1126/science.1071987, 2002.

Dall'Osto, M., Ovadnevaite, J., Paglione, M., Beddows, D. C. S., Ceburnis, D., Cree, C., Cortés, P., Zamanillo, M., Nunes, S. O., Pérez, G. L., Ortega-Retuerta, E., Emelianov, M., Vaqué, D., 
Marrasé, C., Estrada, M., Sala, M. M., Vidal, M., Fitzsimons, M. F., Beale, R., Airs, R., Rinaldi, M., Decesari, S., Facchini, M. C., Harrison, R. M., O'dowd, C., and Simó, R.: Antarctic sea ice region as a source of biogenic organic nitrogen in aerosols, Sci. Rep., 7, 6047, https://doi.org/10.1038/s41598-017-06188-x, 2017.

Dall'Osto, M., Simó, R., Harrison, R. M., Beddows, D. C. S., Saiz-Lopez, A., Lange, R., Skov, H., Nøjgaard, J. K., Nielsen, I. E., and Massling, A.: Abiotic and biotic sources influencing spring new particle formation in North East Greenland, Atmos. Environ., 190, 126-134, https://doi.org/10.1016/j.atmosenv.2018.07.019, 2018.

Deppeler, S. L. and Davidson, A. T.: Southern Ocean phytoplankton in a changing climate, Front. Mar. Sci., 4, 40, https://doi.org/10.3389/fmars.2017.00040, 2017.

Draxler, R. R. and Hess, G. D.: An overview of the HYSPLIT_4 modelling system for trajectories, Aust. Meteorol. Mag., 47, 295-308, 1998.

Galí, M., Devred, E., Levasseur, M., Royer, S.-J., and Babin, M.: A remote sensing algorithm for planktonic dimethylsulfoniopropionate (DMSP) and an analysis of global patterns, Remote Sens. Environ., 171, 171-184, https://doi.org/10.1016/j.rse.2015.10.012, 2015.

Gibson, J. A. E., Garrick, R. C., Burton, H. R., and McTaggart, A. R.: Dimethylsulfide and the algaPhaeocystis pouchetii in antarctic coastal waters, Mar. Biol., 104, 339-346, https://doi.org/10.1007/BF01313276, 1990.

Giordano, M. R., Kalnajs, L. E., Avery, A., Goetz, J. D., Davis, S. M., and DeCarlo, P. F.: A missing source of aerosols in Antarctica-beyond long-range transport, phytoplankton, and photochemistry, Atmos. Chem. Phys., 17, 1-20, https://doi.org/10.5194/acp-17-1-2017, 2017.

Goffart, A., Catalano, G., and Hecq, J. H.: Factors controlling the distribution of diatoms and Phaeocystis in the Ross Sea, J. Mar. Syst., 27, 161-175, https://doi.org/10.1016/S09247963(00)00065-8, 2000.

Haëntjens, N., Boss, E., and Talley, L. D.: Revisiting Ocean Color algorithms for chlorophyll a and particulate organic carbon in the Southern Ocean using biogeochemical floats, J. Geophys. Res.Oceans, 122, 6583-6593, https://doi.org/10.1002/2017jc012844, 2017.

Hatton, A. D. and Wilson, S. T.: Particulate dimethylsulphoxide and dimethylsulphoniopropionate in phytoplankton cultures and Scottish coastal waters, Aquat. Sci., 69, 330-340, https://doi.org/10.1007/s00027-007-0891-4, 2007.

IPCC: Climate change 2013: The physical science basis, Intergovernmental panel on Climate Change, Cambridge University Press, New York, USA, 571-740, 2013.

Ito, T.: Antarctic submicron aerosols and long-range transport of pollutants, Ambio, 34-41, 1989.

Järvinen, E., Virkkula, A., Nieminen, T., Aalto, P. P., Asmi, E., Lanconelli, C., Busetto, M., Lupi, A., Schioppo, R., Vitale, V., Mazzola, M., Petäjä, T., Kerminen, V.-M., and Kulmala, M.: Seasonal cycle and modal structure of particle number size distribution at Dome C, Antarctica, Atmos. Chem. Phys., 13, 7473-7487, https://doi.org/10.5194/acp-13-7473-2013, 2013.

Jimenez, J. L., Canagaratna, M. R., Donahue, N. M., Prevot, A. S., Zhang, Q., Kroll, J. H., DeCarlo, P. F., Allan, J. D., Coe, H., Ng, N. L., Aiken, A. C., Docherty, K. S., Ulbrich, I. M.,
Grieshop, A. P., Robinson, A. L., Duplissy, J., Smith, J. D., Wilson, K. R., Lanz, V. A., Hueglin, C., Sun, Y. L., Tian, J., Laaksonen, A., Raatikainen, T., Rautiainen, J., Vaattovaara, P., Ehn, M., Kulmala, M., Tomlinson, J. M., Collins, D. R., Cubison, M. J., Dunlea, E. J., Huffman, J. A., Onasch, T. B., Alfarra, M. R., Williams, P. I., Bower, K., Kondo, Y., Schneider, J., Drewnick, F., Borrmann, S., Weimer, S., Demerjian, K., Salcedo, D., Cottrell, L., Griffin, R., Takami, A., Miyoshi, T., Hatakeyama, S., Shimono, A., Sun, J. Y., Zhang, Y. M., Dzepina, K., Kimmel, J. R., Sueper, D., Jayne, J. T., Herndon, S. C., Trimborn, A. M., Williams, L. R., Wood, E. C., Middlebrook, A. M., Kolb, C. E., Baltensperger, U., and Worsnop, D. R.: Evolution of organic aerosols in the atmosphere, Science, 326, 1525-1529, https://doi.org/10.1126/science.1180353, 2009.

Jokinen, T., Sipilä, M., Kontkanen, J., Vakkari, V., Tisler, P., Duplissy, E.-M., Junninen, H., Kangasluoma, J., Manninen, H. E., Petäjä, T., Kulmala, M., Worsnop, D. R., Kirkby, J., Virkkula, A., and Kerminen, V.-M.: Ion-induced sulfuric acid-ammonia nucleation drives particle formation in coastal Antarctica, Sci. Adv., 4, eaat9744, https://doi.org/10.1126/sciadv.aat9744, 2018.

Keller, M. D., Bellows, W. K., and Guillard, R. R. L.: Dimethyl sulfide production in marine phytoplankton, in: Biogenic sulfur in the environment, ACS Symposium Series, 393, edited by: Saltzman E. S. and Cooper W. J., American Chemical Society, Washington, DC, USA, 167-182, 1989.

Kerminen, V.-M., Chen, X., Vakkari, V., Petäjä, T., Kulmala, M., and Bianchi, F.: Atmospheric new particle formation and growth: review of field observations, Environ. Res. Lett., 13, 103003, https://doi.org/10.1088/1748-9326/aadf3c, 2018.

Kim, J., Yoon, Y. J., Gim, Y., Kang, H. J., Choi, J. H., Park, K.-T., and Lee, B. Y.: Seasonal variations in physical characteristics of aerosol particles at the King Sejong Station, Antarctic Peninsula, Atmos. Chem. Phys., 17, 12985-12999, https://doi.org/10.5194/acp-17-12985-2017, 2017.

Kim, J., Yoon, Y. J., Gim, Y., Choi, J. H., Kang, H. J., Park, K.-T., Park, J., and Lee, B. Y.: New particle formation events observed at King Sejong Station, Antarctic Peninsula - Part 1: Physical characteristics and contribution to cloud condensation nuclei, Atmos. Chem. Phys., 19, 7583-7594, https://doi.org/10.5194/acp19-7583-2019, 2019.

Kim, T.-W., Lee, K., Najjar, R. G., Jeong, H.-D., and Jeong, H. J.: Increasing $\mathrm{N}$ abundance in the northwestern Pacific Ocean due to atmospheric nitrogen deposition, Science, 334, 505-509, https://doi.org/10.1126/science.1206583, 2011.

Kirkby, J., Duplissy, J., Sengupta, K., Frege, C., Gordon, H., Williamson, C., Heinritzi, M., Simon, M., Yan, C., Almeida, J., Tröstl, J., Nieminen, T., Ortega, I. K., Wagner, R., Adamov, A., Amorim, A., Bernhammer, A.-K., Bianchi, F., Breitenlechner, M., Brilke, S., Chen, X., Craven, J., Dias, A., Ehrhart, S., Flagan, R. C., Franchin, A., Fuchs, C., Guida, R., Hakala, J., Hoyle, C. R., Jokinen, T., Junninen, H., Kangasluoma, J., Kim, J., Krapf, M., Kürten, A., Laaksonen, A., Lehtipalo, K., Makhmutov, V., Mathot, S., Molteni, U., Onnela, A., Peräkylä, O., Piel, F., Petäjä, T., Praplan, A. P., Pringle, K., Rap, A., Richards, N. A. D., Riipinen, I., Rissanen, M. P., Rondo, L., Sarnela, L., Schobesberger, S., Scott, C. E., Seinfeld, J. H., Sipilä, M., Steiner, G., Stozhkov, Y., Stratmann, F., Tomé, A., Virtanen, A., Vogel, A. L., Wagner, A. C., Wagner, P. E., Weingartner, E., Wimmer, D., Winkler, P. M., Ye, P., Zhang, X., Hansel, A., Dommen, J., Donahue, N. 
M., Worsnop, D. R., Baltensperger, U., Kulmala, M., Carslaw, K. S., and Curtius, J.: Ion-induced nucleation of pure biogenic particles, Nature, 533, 521, https://doi.org/10.1038/nature17953, 2016.

Korhonen, P., Kulmala, M., Laaksonen, A., Viisanen, Y., McGraw, R., and Seinfeld, J. H.: Ternary nucleation of $\mathrm{H}_{2} \mathrm{SO}_{4}, \mathrm{NH}_{3}$, and $\mathrm{H}_{2} \mathrm{O}$ in the atmosphere, J. Geophys. Res.-Atmos., 104, 2634926353, https://doi.org/10.1029/1999JD900784, 1999.

Kropuenske, L. R., Mills, M. M., van Dijken, G. L., Bailey, S., Robinson, D. H., Welschmeyer, N. A., and Arrigo, K. R.: Photophysiology in two major Southern Ocean phytoplankton taxa: Photoprotection in Phaeocystis antarctica and Fragilariopsis cylindrus, Limnol. Oceanogr., 54, 1176-1196, https://doi.org/10.4319/1o.2009.54.4.1176, 2009.

Kulmala, M. and Laaksonen, A.: Binary nucleation of waer-sulfuric acid system: Comparison of classical theories with different $\mathrm{H}_{2} \mathrm{SO}_{4}$ saturation vapor pressures, J. Chem. Phys., 93, 696-701, https://doi.org/10.1063/1.459519, 1990.

Kyrö, E.-M., Kerminen, V.-M., Virkkula, A., Dal Maso, M., Parshintsev, J., Ruíz-Jimenez, J., Forsström, L., Manninen, H. E., Riekkola, M.-L., Heinonen, P., and Kulmala, M.: Antarctic new particle formation from continental biogenic precursors, Atmos. Chem. Phys., 13, 3527-3546, https://doi.org/10.5194/acp13-3527-2013, 2013.

Lana, A., Bell, T. G., Simó, R., Vallina, S. M., Ballabrera-Poy, J., Kettle, A. J., Dachs, J., Bopp, L., Saltzman, E. S., Stefels, J., Johnson, J. E., and Liss, P. S.: An updated climatology of surface dimethlysulfide concentrations and emission fluxes in the global ocean, Global Biogeochem. Cy., 25, GB1004, https://doi.org/10.1029/2010gb003850, 2011.

Laturnus, F., Wiencke, C., and Klöser, H.: Antarctic macroalgae - sources of volatile halogenated organic compounds, Mar. Environ. Res., 41, 169-181, https://doi.org/10.1016/01411136(95)00017-8, 1996.

Leck, C. and Bigg, E. K.: Source and evolution of the marine aerosol - A new perspective, Geophys. Res. Lett., 32, L19803, https://doi.org/10.1029/2005GL023651, 2005.

Lee, S.-H., Reeves, J. M., Wilson, J. C., Hunton, D. E., Viggiano, A. A., Miller, T. M., Ballenthin, J. O., and Lait, L. R.: Particle formation by ion nucleation in the upper troposphere and lower stratosphere, Science, 301, 1886-1889, https://doi.org/10.1126/science.1087236, 2003.

Lovejoy, E. R., Curtius, J., and Froyd, K. D.: Atmospheric ioninduced nucleation of sulfuric acid and water, J. Geophys. Res.Atmos., 109, D08204, https://doi.org/10.1029/2003JD004460, 2004.

Malviya, S., Scalco, E., Audic, S., Vincent, F., Veluchamy, A., Poulain, J., Wincker, P., Iudicone, D., de Vargas, C., Bittner, L., Zingone, A., and Bowler, C.: Insights into global diatom distribution and diversity in the world's ocean, P. Natl. Acad. Sci. USA, 113, E1516-E1525, https://doi.org/10.1073/pnas.1509523113, 2016.

Merikanto, J., Spracklen, D. V., Mann, G. W., Pickering, S. J., and Carslaw, K. S.: Impact of nucleation on global CCN, Atmos. Chem. Phys., 9, 8601-8616, https://doi.org/10.5194/acp-9-86012009, 2009.

Minikin, A., Legrand, M., Hall, J., Wagenbach, D., Kleefeld, C., Wolff, E., Pasteur, E. C., and Ducroz, F.: Sulfur-containing species (sulfate and methanesulfonate) in coastal Antarctic aerosol and precipitation, J. Geophys. Res.-Atmos., 103, 1097510990, https://doi.org/10.1029/98JD00249, 1998.

Mishra, V. K., Kim, K.-H., Hong, S., and Lee, K.: Aerosol composition and its sources at the King Sejong Station, Antarctic peninsula, Atmos. Environ., 38, 4069-4084, https://doi.org/10.1016/j.atmosenv.2004.03.052, 2004.

Mustapha, Z. B., Alvain, S., Jamet, C., Loisel, H., and Dessailly, D.: Automatic classification of water-leaving radiance anomalies from global SeaWiFS imagery: application to the detection of phytoplankton groups in open ocean waters, Remote Sens. Environ., 146, 97-112, https://doi.org/10.1016/j.rse.2013.08.046, 2014.

Navarro, G., Alvain, S., Vantrepotte, V., and Huertas, I. E.: Identification of dominant phytoplankton fuctional types in the Mediterranean Sea based on a regionalized remote sensing approach, Remote Sens. Environ., 152, 557-575, https://doi.org/10.1016/j.rse.2014.06.029, 2014.

O'Dowd, C. and De Leeuw, G.: Marine aerosol production: a review of the current knowledge, Philos. T. Roy. Soc. A, 365, 17531774, https://doi.org/10.1098/rsta.2007.2043, 2007.

O’Dowd, C. D., Facchini, M. C., Cavalli, F., Ceburnis, D., Mircea, M., Decesari, S., Fuzzi, S., Yoon, Y. J., and Putaud, J.-P.: Biogenically driven organic contribution to marine aerosol, Nature, 431, 676-680, https://doi.org/10.1038/nature02959, 2004.

Park, J., Park, T., Yang, E. J., Kim, D., Gorbunov, M. Y., Kim, H.-C., Kang, S. H., Shin, H. C., Lee, S., and Yoo, S.: Early summer iron limitation of phytoplankton photosynthesis in the Scotia Sea as inferred from fast repetition rate fluorometry, J. Geophys. Res.Oceans, 118, 3795-3806, https://doi.org/10.1002/jgrc.20281, 2013a.

Park, K.-T., Lee, K., Yoon, Y.-J., Lee, H.-W., Kim, H.C., Lee, B.-Y., Hermansen, O., Kim, T.-W., and Holmén, K.: Linking atmospheric dimethyl sulfide and the Arctic Ocean spring bloom, Geophys. Res. Lett., 40, 155-160, https://doi.org/10.1029/2012GL054560, 2013b.

Park, K.-T., Lee, K., Shin, K., Yang, E. J., Hyun, B., Kim, J. M., Noh, J. H., Kim, M., Kong, B., Choi, D. H., Choi, S.-J., Jang, P.-G., and Jeong, H. J.: Direct Linkage between Dimethyl Sulfide Production and Microzooplankton Grazing, Resulting from Prey Composition Change under High Partial Pressure of Carbon Dioxide Conditions, Environ. Sci. Technol., 48, 4750-4756, https://doi.org/10.1021/es403351h, 2014a.

Park, K.-T., Lee, K., Shin, K., Jeong, H. J., and Kim, K. Y.: Improved method for minimizing sulfur loss in analysis of particulate organic sulfur, Anal. Chem., 86, 1352-1356, https://doi.org/10.1021/ac403649m, 2014b.

Park, K.-T., Jang, S., Lee, K., Yoon, Y. J., Kim, M.-S., Park, K., Cho, H.-J., Kang, J.-H., Udisti, R., Lee, B.-Y., and Shin, K.-H.: Observational evidence for the formation of DMS-derived aerosols during Arctic phytoplankton blooms, Atmos. Chem. Phys., 17, 9665-9675, https://doi.org/10.5194/acp-17-9665-2017, 2017.

Park, K.-T., Lee, K., Kim, T.-W., Yoon, Y. J., Jang, E.H., Jang, S., Lee, B.-Y., and Hermansen, O.: Atmospheric DMS in the Arctic Ocean and its relation to phytoplankton biomass, Global Biogeochem. Cy., 32, 351-359, https://doi.org/10.1002/2017GB005805, 2018.

Polimene, L., Archer, S. D., Butenschön, M., and Allen, J. I.: A mechanistic explanation of the Sargasso Sea 
DMS “summer paradox", Biogeochemistry, 110, 243-255, https://doi.org/10.1007/s10533-011-9674-z, 2012.

Preunkert, S., Legrand, M., Jourdain, B., Moulin, C., Belviso, S., Kasamatsu, N., Fukuchi, M., and Hirawake, T.: Interannual variability of dimethylsulfide in air and seawater and its atmospheric oxidation by-products (methanesulfonate and sulfate) at Dumont d'Urville, coastal Antarctica (1999-2003), J. Geophys. Res.Atmos., 112, D06306, https://doi.org/10.1029/2006JD007585, 2007.

Preunkert, S., Jourdain, B., Legrand, M., Udisti, R., Becagli, S., and Cerri, O.: Seasonality of sulfur species (dimethyl sulfide, sulfate, and methanesulfonate) in Antarctica: Inland versus coastal regions, J. Geophys. Res.-Atmos., 113, D15302, https://doi.org/10.1029/2008JD009937, 2008.

Prospero, J. M., Savoie, D. L., Saltzman, E. S., and Larsen, R.: Impact of Oceanic Sources of Biogenic Sulfur on Sulfate Aerosol Concentrations at Mawson, Antarctica, Nature, 350, 221-223, https://doi.org/10.1038/350221a0, 1991.

Read, K. A., Lewis, A. C., Bauguitte, S., Rankin, A. M., Salmon, R. A., Wolff, E. W., Saiz-Lopez, A., Bloss, W. J., Heard, D. E., Lee, J. D., and Plane, J. M. C.: DMS and MSA measurements in the Antarctic Boundary Layer: Impact of BrO on MSA production, Atmos. Chem. Phys., 8, 2985-2997, https://doi.org/10.5194/acp8-2985-2008, 2008.

Reisch, C. R., Moran, M. A., and Whitman, W. B.: Bacterial catabolism of dimethylsulfoniopropionate (DMSP), Front. Microbiol., 2, 172, https://doi.org/10.3389/fmicb.2011.00172, 2011.

Sanchez, K. J., Chen, C.-L., Russell, L. M., Betha, R., Liu, J., Price, D. J., Massoli, P., Ziemba, L. D., Crosbie, E. C., Moore, R. H., Müller, M., Schiller, S. A., Wisthaler, A., Lee, A. K. Y., Quinn, P. K., Bates, T. S., Porter, J., Bell, T. G., Saltzman, E. S., Vaillancourt, R. D., and Behrenfeld, M. J.: Substantial seasonal contribution of observed biogenic sulfate particles to cloud condensation nuclei, Sci. Rep., 8, 3235, https://doi.org/10.1038/s41598018-21590-9, 2018.

Savoie, D. L., Prospero, J. M., Larsen, R. J., Huang, F., Izaguirre, M. A., Huang, T., Snowdon, T. H., Custals, L., and Sanderson, C. G.: Nitrogen and Sulfur Species in Antarctic Aerosols at Mawson, Palmer Station, and Marsh (King George Island), J. Atmos. Chem., 17, 95-122, https://doi.org/10.1007/BF00702821, 1993.

Schoemann, V., Becquevort, S., Stefels, J., Rousseau, W., and Lancelot, C.: Phaeocystis blooms in the global ocean and their controlling mechanisms: a review, J. Sea Res., 53, 43-66, https://doi.org/10.1016/j.seares.2004.01.008, 2005.

Sedwick, P. N., Garcia, N. S., Riseman, S. F., Marsay, C. M., and DiTullio, G. R.: Evidence for high iron requirements of colonial Phaeocystis antarctica at low irradiance, Biogeochemistry, 83, 83-97, https://doi.org/10.1007/s10533-007-9081-7, 2007.

Shiraiwa, M., Li, Y., Tsimpidi, A. P., Karydis, V. A., Berkemeier, T., Pandis, S. N., Lelieveld, J., Koop, T., and Pöschl, U.: Global distribution of particle phase state in atmospheric secondary organic aerosols, Nat. Commun., 8, 15002, https://doi.org/10.1038/ncomms15002, 2017.

Siegel, D. A., Behrenfeld, M. J., Maritorena, S., McClain, C. R., Antoine, D., Bailey, S. W., Bontempi, P. S., Boss, E. S., Dierssen, H. M., Doney, S. C., Eplee Jr., R. E., Evans, R. H., Feldman, G. C., Fields, E., Franz, B. A., Kuring, N. A., Mengelt, C., Nelson, N. B., Patt, F. S., Robinson, W. D., Sarmiento, J. L., Swan, C.
M., Werdell, P. J., Westberry, T. K., Wilding, J. G., and Yoder, J. A.: Regional to global assessments of phytoplankton dynamics from the SeaWiFS mission, Remote Sens. Environ., 135, 77-91, https://doi.org/10.1016/j.rse.2013.03.025, 2013.

Simó, R.: Production of atmospheric sulfur by oceanic plankton: biogeochemical, ecological and evolutionary links, Trends. Ecol. Evol., 16, 287-294, https://doi.org/10.1016/S01695347(01)02152-8, 2001.

Sipilä, M., Sarnela, N., Jokinen, T., Henschel, H., Junninen, H., Kontkanen, J., Richters, S., Kangasluoma, J., Franchin, A., Peräkylä, O., Rissanen, M. P., Ehn, M., Vehkamäki, H., Kurten, T., Berndt, T., Petäjä, T., Worsnop, D., Ceburnis, D., Kerminen, V.-M., Kulmala, M., and O'Dowd, C.: Molecular-scale evidence of aerosol particle formation via sequential addition of HIO 3, Nature, 537, 532, https://doi.org/10.1038/nature19314, 2016.

Stefels, J., Steinke, M., Turner, S., Malin, G., and Belviso, S.: Environmental constraints on the production and removal of the climatically active gas dimethylsulphide (DMS) and implications for ecosystem modelling, Biogeochemistry, 83, 245-275, https://doi.org/10.1007/s10533-007-9091-5, 2007.

Sullivan, C. W., Arrigo, K. R., McClain, C. R., Comiso, J. C., and Firestone, J.: Distributions of phytoplankton blooms in the southern ocean, Science, 262, 1832-1837, https://doi.org/10.1126/science.262.5141.1832, 1993.

Sullivan, R. C., Crippa, P., Matsui, H., Leung, L. R., Zhao, C., Thota, A., and Pryor, S. C.: New particle formation leads to cloud dimming, Clim. Atmos. Sci., 1, 9, https://doi.org/10.1038/s41612-018-0019-7, 2018.

Tison, J.-L., Brabant, F., Dumont, I., and Stefels, J.: High-resolution dimethyl sulfide and dimethylsulfoniopropionate time series profiles in decaying summer first-year sea ice at Ice Station Polarstern, western Weddell Sea, Antarctica, J. Geophys. Res.Biogeo., 115, G04044, https://doi.org/10.1029/2010JG001427, 2010.

Todd, J. D., Rogers, R., Li, Y. G., Wexler, M., Bond, P. L., Sun, L., Curson, A. R. J., Malin, G., Steinke, M., and Johnston, A. W. B.: Structural and regulatory genes required to make the gas dimethyl sulfide in bacteria, Science, 315, 666-669, https://doi.org/10.1126/science.1135370, 2007.

Turner, J., Colwell, S. R., Marshall, G. J., Lachlan-Cope, T. A., Carleton, A. M., Jones, P. D., Lagun, V., Reid, P. A., and Iagovkina, S.: Antarctic climate change during the last 50 years, Int. J. Climatol., 25, 279-294, https://doi.org/10.1002/joc.1130, 2005.

Weber, L. H. and El-Sayed, S. Z.: Contributions of the net, nanoand picoplankton to the phytoplankton standing crop and primary productivity in the Southern Ocean, J. Plankton Res., 9, 973-994, https://doi.org/10.1093/plankt/9.5.973, 1987.

Weber, R. J., McMurry, P. H., Mauldin, L., Tanner, D. J., Eisele, F. L., Brechtel, F. J., Kreidenweis, S. M., Kok, G. L., Schillawski, R. D., and Baumgardner, D.: A study of new particle formation and growth involving biogenic and trace gas species measured during ACE 1, J. Geophys. Res.-Atmos., 103, 16385-16396, https://doi.org/10.1029/97JD02465, 1998.

Weller, R., Schmidt, K., Teinilä, K., and Hillamo, R.: Natural new particle formation at the coastal Antarctic site Neumayer, Atmos. Chem. Phys., 15, 11399-11410, https://doi.org/10.5194/acp-1511399-2015, 2015.

Westervelt, D. M., Pierce, J. R., and Adams, P. J.: Analysis of feedbacks between nucleation rate, survival probability and cloud 
condensation nuclei formation, Atmos. Chem. Phys., 14, 55775597, https://doi.org/10.5194/acp-14-5577-2014, 2014.

Yu, F. Q. and Luo, G.: Oceanic Dimethyl Sulfide Emission and New Particle Formation around the Coast of Antarctica: A Modeling Study of Seasonal Variations and Comparison with Measurements, Atmos.-Basel, 1, 34-50, https://doi.org/10.3390/atmos1010034, 2010.
Zhang, M., Chen, L., Xu, G., Lin, Q., and Liang, M.: Linking phytoplankton activity in polynyas and sulfur aerosols over Zhongshan Station, East Antarctica, J. Atmos. Sci., 72, 4629-4642, https://doi.org/10.1175/JAS-D-15-0094.1, 2015. 